\title{
JOSÉ VALERIO ARGÜELLO (1862-1946): ARTISTA IMAGINERO
}

\author{
José Valerio Argüello (1862-1946): religious imagery artist
}

Miguel Bolaños Sequeira

Jubilado, Costa Rica

miguel.bolanoss@gmail.com

Magda Barrantes Campos

Jubilada, Costa Rica

m_barrantes@hotmail.com

Luis Carlos Bonilla Soto

Curia Metropolitana de San José, Costa Rica

lcbonillasoto@gmail.com

Recibido: 27-10-2021

Aprobado: 23-11-2021

Miguel Bolaños Sequeira es licenciado en Ingeniería Civil por la Universidad de Costa Rica (1981) y master en Valuación por la Benemérita Universidad Autónoma de Puebla, México, (2003). Actualmente está jubilado.

Magda Barrantes Campos es asesora en recursos humanos y en gestión de riesgos naturales en su propio despacho, actualmente está jubilada.

Luis Carlos Bonilla Soto es Licenciado en Sociología por la Universidad de Costa Rica (2009). Investigador de Arte Sacro y Piedad Popular en la Curia Metropolitana de San José, Costa Rica y docente en la Universidad Estatal a Distancia.

\section{RESUMEN}

José Valerio Argüello fue un artista de imaginería religiosa que creó un importante grupo de esculturas para las iglesias católicas y prácticas familiares devocionales en distintos lugares de Costa Rica. Sin embargo, su arte es desconocido y su vida ha sido olvidada durante las últimas cinco décadas. El objetivo de este artículo es mostrar algunos detalles de la vida de este artista, su papel en la creación de la imaginería católica costarricense y trazar un camino para nuevas investigaciones sobre este tipo de artistas que jugaron un papel fundamental en la historia del arte local.

Palabras clave: escultura; arte sacro; imaginería; José Valerio; Costa Rica

\section{ABSTRACT}

Jose Valerio Argüello was a religious imagery artist who created an important group of sculptures for catholic churches and devocional family practices in different places around Costa Rica. Nevertheless, his art is unknown and his life has been forgotten through the last five decades. The aim of this article is to present some details of the life of this artist, and his role in costa rican catholic imagery creation and also to draw a path for new research about this kind of artists, who played as pivot in local art history.

Keywords: sculpture; sacred art; imagery art; José Valerio; Costa Rica 
Revista Herencia, Vol. 35 (1), enero-junio, 2022.

\section{La imaginería como práctica artística en Costa Rica}

José de Jesús Valerio Argüello forma parte de la lista de artistas imagineros costarricenses que ingeniaron, esculpieron, policromaron y doraron múltiples piezas de índole religiosa para el culto doméstico y el culto litúrgico en las iglesias en este país centroamericano, sin embargo se conoce poco sobre su vida pese a que su obra se desarrolló en un periodo histórico reciente, desde finales del siglo XIX hasta inicios de la segunda mitad del siglo XX (Ferrero, 2004; Jiménez, 2012; González, 2018).

La obra del escultor José Valerio Argüello está esparcida por todo el país, pero no ha sido posible determinar en detalle cuántas fueron ejecutadas por él en sus 67 años de incesante labor, siendo las últimas conocidas las que datan de 1944. En el libro Sociedad y Arte en la Costa Rica del Siglo XIX (2004), Luis Ferrero indica que José Valerio era tan famoso como lo fueron los imagineros Miguel y Serapio Ramos, así como José Zamora, el Viejo.

Para comprender la vida y obra de Valerio Argüello es necesario precisar que la imaginería católica consiste en el arte de representar los misterios de la divinidad y de las figuras del santoral de la fe cristiana por medio de la escultura, soportada en diversos materiales (Méndez, 1997), en el caso de América Latina se privilegió la madera (por lo general policromada), para propiciar la devoción y el culto religioso, tanto público como privado según la función mistagógica, señalada por san Juan Damasceno, por medio de la cual se reproduce una semejanza y un modelo de aquello sagrado que se representa (Carrera-Umaña, 2020). 
Figura 1. Vistas laterales y frontal del Ángel de Adoración, iglesia parroquial de san Vicente de Moravia
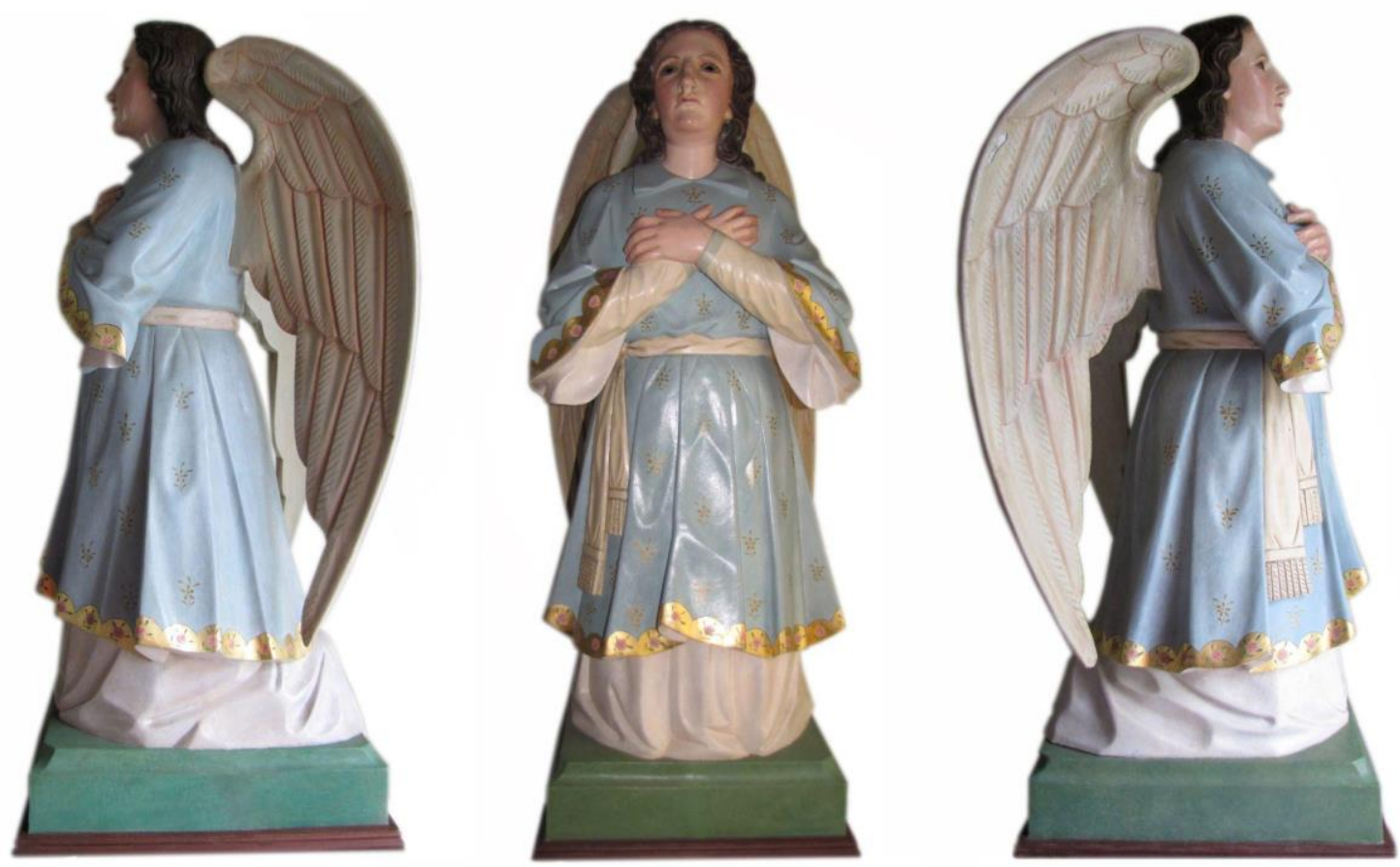

Fotografías: Luis Carlos Bonilla Soto

Cabe indicar que la figuración de las Personas Divinas y de las personas canonizadas con el estatus de santas, se remonta a los primeros siglos del cristianismo y dicha práctica artística-religiosa ha estado sometida a discusión y debate hasta el presente, ya fuera por motivos teológicos, ideológicos o estéticos (Dieguéz-Melo, 2016). No obstante, pese a los encuentros y desencuentros alrededor de este tipo de arte, la imaginería ha estado ligada a la necesidad humana de traer a la memoria todo aquello que le recuerda la acción divina para impulsar la vida presente y fijar un referente para la vida futura.

Desde el catolicismo se afirma que la confección de obras de este tipo es una forma por la cual se registra "con amor las imágenes de los hombres virtuosos del pasado, para que sirvan de estímulo, para guardar su memoria y para que nos estimulen" (Damasceno citado por Carrera-Umaña, 2020, p. 122). De modo que la obra en sí se transforma en vehículo para mediar súplicas, obtener favores y tributar acciones de gracias. 
Revista Herencia, Vol. 35 (1), enero-junio, 2022.

Una de las razones por las cuales la imaginería religiosa no fue considerada con el estatus de arte propiamente dicho, se debe a que este tipo de obras era señalado como algo carente de genio creativo debido a estar sujetas al canon dogmático eclesial y reproducir temas repetitivos para usos devocionales de la población (Lorite-Cruz, 2010), que en el caso de Costa Rica, estos usos fueron mayoritariamente extendidos hasta las últimas décadas del siglo XX.

La sistemática exclusión de los imagineros del mundo de las bellas artes y de la historia de las artes plásticas en Costa Rica, ha generado un desconocimiento generalizado sobre los procesos de creación y de las obras individualizadas producidas por estos hacedores de arte religioso reducidos a simples artesanos, lo que ha provocado que la información existente esté dispersa y, en el mejor de los casos, conservada por los familiares descendientes de estos (Bonilla-Soto, 2018 y 2019).

El proceso de creación de imaginería católica en Costa Rica, en el período de trabajo del imaginero José Valerio, se remite a los talleres fundados alrededor de la figura de un maestro, quien instruía a los aprendices por medio de la enseñanza de las técnicas requeridas para la confección de las esculturas para el culto, ya fueran de bulto redondo (figuras de gracia) o de candelero (figuras de bastidor para vestir), principalmente en dos áreas: la talla en madera y el policromado (Méndez, 1997; Rojas, 2008), sin embargo, en el caso de Valerio no se ha podido documentar una lógica de este tipo.

Los talleres de imaginería religiosa, al igual que muchos oficios artesanales y artísticos, por lo general se encontraban contiguo a los domicilios de los maestros creadores, de modo que era común que se entremezclara el trabajo productivo con la esfera de la intimidad doméstica. Al respecto, se debe considerar que Costa Rica, durante el periodo histórico en que vivió Valerio, fue una sociedad ligada eminentemente al sector agropecuario, con predominancia del cultivo del café para la exportación y de la producción familiar de otros productos para el autoconsumo (BolañosVillalobos, 1999), de modo que la especialización social del trabajo era limitada en esa época.

Teniendo en cuenta este contexto, lo que a continuación se expone tiene por objetivo brindar datos biográficos de José Valerio Argüello y presentar algunas de las obras de imaginería elaboradas por este autor, con miras a plasmar elementos que permitan dibujar un panorama sobre su vida artística, 
Revista Herencia, Vol. 35 (1), enero-junio, 2022.

a través de información recuperada de la tradición oral familiar y registros documentales, así como para dejar constancia de su legado artístico por medio de la identificación y registro de obras en distintas colecciones en Costa Rica.

Figura 2. Crucifijo (1931) entregado por José Valerio a su nieta Carmen Bolaños Valerio el día de su matrimonio con Cristian García. Se observan las etiquetas colocadas para la exposición realizada en la sala Julián Marchena del MAC (el número 26 del consecutivo de obras en la esquina superior izquierda coincide con el número de obra en el catálogo impreso).
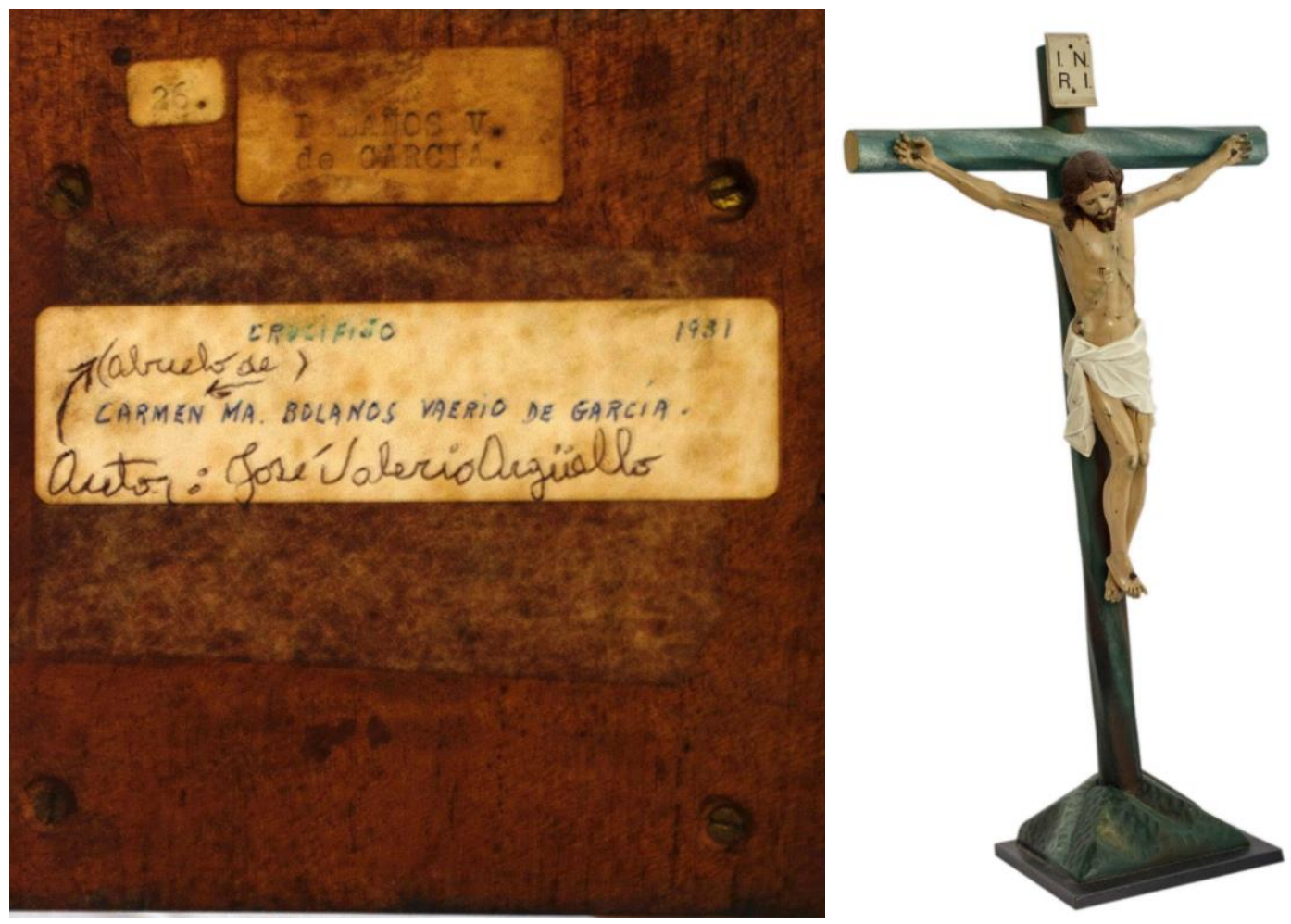

Fotografías: Miguel Bolaños Sequeira 
Revista Herencia, Vol. 35 (1), enero-junio, 2022.

\section{Una metodología para acercarse a la obra de Valerio Argüello}

Las preguntas de investigación que han guiado el proceso de recuperación, sistematización e interpretación de la información son: ¿Cómo fue la vida cotidiana de José Valerio como artista dedicado a la imaginería religiosa? ¿Dónde se encuentran las obras por él realizadas? ¿Cuáles son los rasgos artísticos, en las obras de arte por él elaboradas, que permiten definir su estilo?

Para formular respuestas a dichas interrogantes se recurrió a dos tipos de fuentes: documentales y orales. Las documentales son principalmente anécdotas familiares escritas, notas de prensa, informes, inventarios y catálogos de arte. Las orales corresponden a narraciones y referencias dadas por familiares, personas que conservan obras elaboradas por dicho autor y personas conocedoras del patrimonio artístico costarricense.

Para sistematizar la información se observaron en paralelo dos variables: 1. Momentos de la vida del autor y su familia y 2. Obras que pueden corresponder a ese momento de vida. Para ello, se rastrearon las obras de la familia que fueron expuestas en la exhibición sobre la obra del escultor en la Sala Julián Marchena, del Museo de Arte Costarricense (MAC), entre el 7 de diciembre de 1978 y el 7 de enero de 1979.

Dicho catálogo es la única documentación hallada sobre la mencionada exposición, pues aunque la ex subdirectora del MAC, la señora Ligia Kooper, señaló vía telefónica que para dicha exhibición ella y el señor Luis Ferrero levantaron un fichero de las obras expuestas, de estas no se da razón en el archivo de dicho museo costarricense. Por lo anterior, las obras se han ido rastreando a partir de la consulta con los familiares. 
Revista Herencia, Vol. 35 (1), enero-junio, 2022.

Figura 3. Estudio de tallado de rostros de obras confirmadas (color) y de obras seleccionadas con posibilidades de atribución (escala de grises).
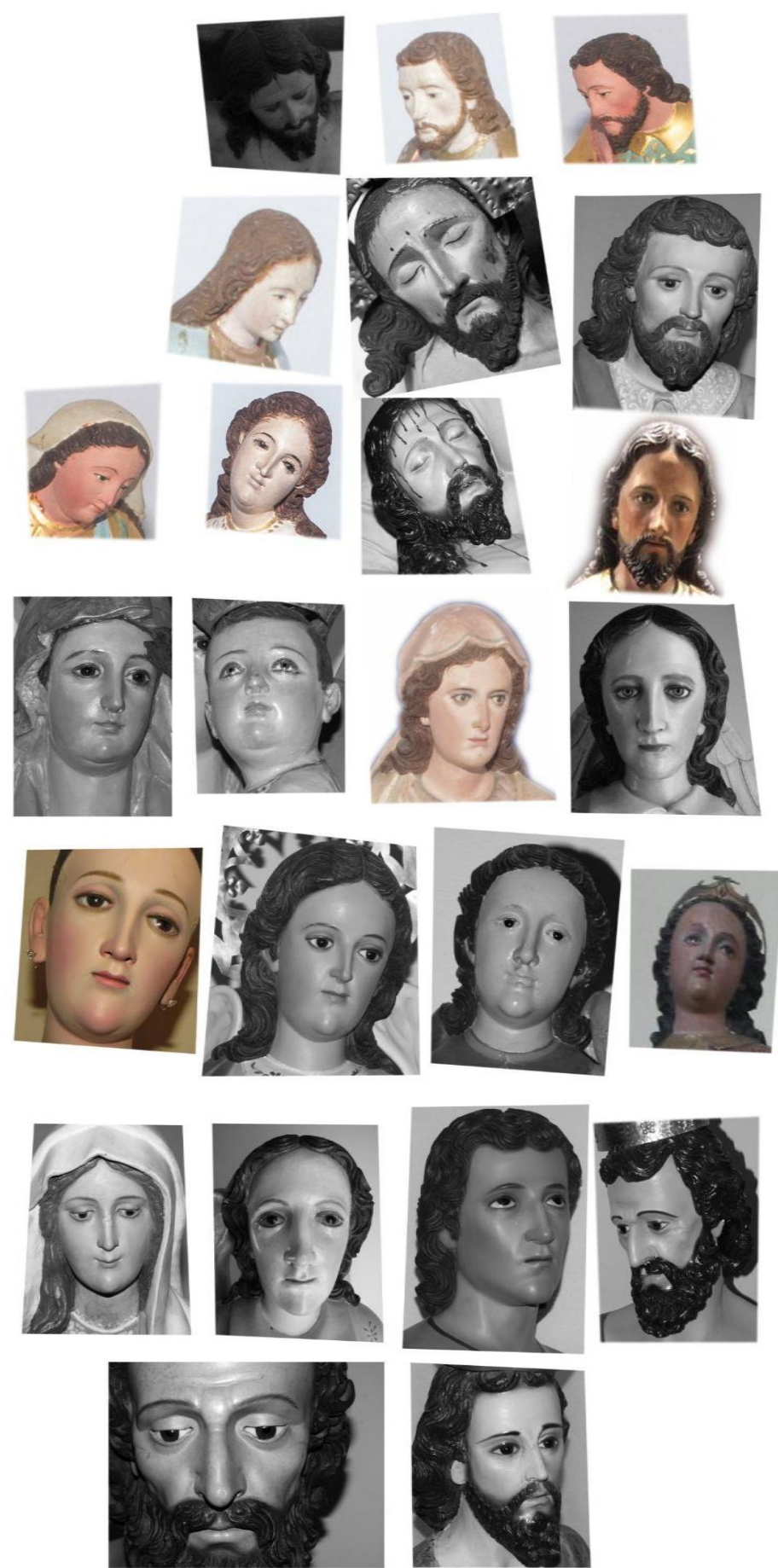

Fotografías: Miguel Bolaños Sequeira y Luis Carlos Bonilla Soto. 
Revista Herencia, Vol. 35 (1), enero-junio, 2022.

En el estudio realizado se analizaron 28 obras escultóricas individualizadas, las cuales incluyen tres conjuntos del nacimiento o pasito tradicional costarricense, que se tiene certeza que fueron realizadas por José Valerio, ya fuera por su firma plasmada o por comprobación de herencia familiar. Luego se realizó una selección de 40 obras dentro de las colecciones de la Arquidiócesis de San José y de la Diócesis de Alajuela, cuyas características y ubicación pudieran estar asociadas al artista en cuestión.

Todas las obras fueron descritas formalmente y, luego, fueron analizadas para comparar las formas escultóricas y la policromía (en caso de que se conservara la original), entre las obras confirmadas y las que podrían ser atribuidas. Para ello se confrontaron patrones en los motivos fitomorfos que el autor pintaba en las vestimentas de los distintos personajes, se observaron detenidamente las secuencias del tallado en los cabellos, los contornos de superficies y las disposiciones anatómicas de las imágenes de bulto redondo, con miras a distinguir rasgos recurrentes. Lo anterior tuvo como resultado la atribución de autoría de 14 obras de imaginería sacra en iglesias de dichas diócesis.

El informe de investigación y las fotografías de las obras recopiladas se pueden consultar en el Archivo de la Curia Metropolitana, con miras a que en futuras investigaciones se puedan confirmar o refutar los hallazgos y, de este modo continuar con los análisis y la realización de nuevas valoraciones de obras que pudieron haber sido manufacturadas por José Valerio, en especial a lo relacionado con las obras de bastidor, pues las características propias de este tipo de imágenes hicieron difícil determinar en cuanto a autorías.

Dicha dificultad para identificar distinciones estilísticas se debe a que, por una parte, en el periodo comprendido desde la segunda mitad del siglo XIX y las primera décadas del siglo XX, se importaron muchas imágenes de vestir desde Guatemala, tal es el caso de las imágenes de Jesús Nazareno de la Catedral de San José y la iglesia parroquial de Santa Ana, la Virgen de La Soledad venerada en la iglesia del mismo nombre o la imagen del patriarca san José encargada por el primer obispo de Costa Rica Anselmo Llorente y la Fuente y, por otra parte, a la existencia en Costa Rica de imagineros que crearon obras de alta calidad según el estilo de arte sacro de los talleres guatemaltecos, lo cual puede provocar un señalamiento de una obra como guatemalteca, cuando pudo ser tallada y encarnada en Costa Rica. 
Revista Herencia, Vol. 35 (1), enero-junio, 2022.

Jiménez (2012), decía que se podría esperar que varias obras de Valerio se encuentren en la Parroquia de Santo Domingo de Heredia, pero considerando que a las iglesias ubicadas en el actual cantón de Santo Domingo también fueron traídas imágenes desde Guatemala, como es el caso del san Miguel de la parroquia del mismo nombre en este distrito domingueño (Vargas-Benavides, 2018) y, al no tener datos documentales ni fuentes orales de la época que puedan determinar el origen de un número considerable de obras allí existentes, es muy aventurado afirmar de dónde procede una $u$ otra imagen, máxime cuando se constata que Valerio tuvo una importante producción, pues sus ingresos familiares estuvieron en función de su oficio como artista imaginero y la calidad de los rostros trabajados por él, indican que tenía las suficientes habilidades para emular los trabajos artísticos logrados en Guatemala.

Figura 4. Firma de José Valerio Argüello tomada de trámite ante Alcaldía Única de Santo Domingo de Heredia, 24 de mayo de 1889

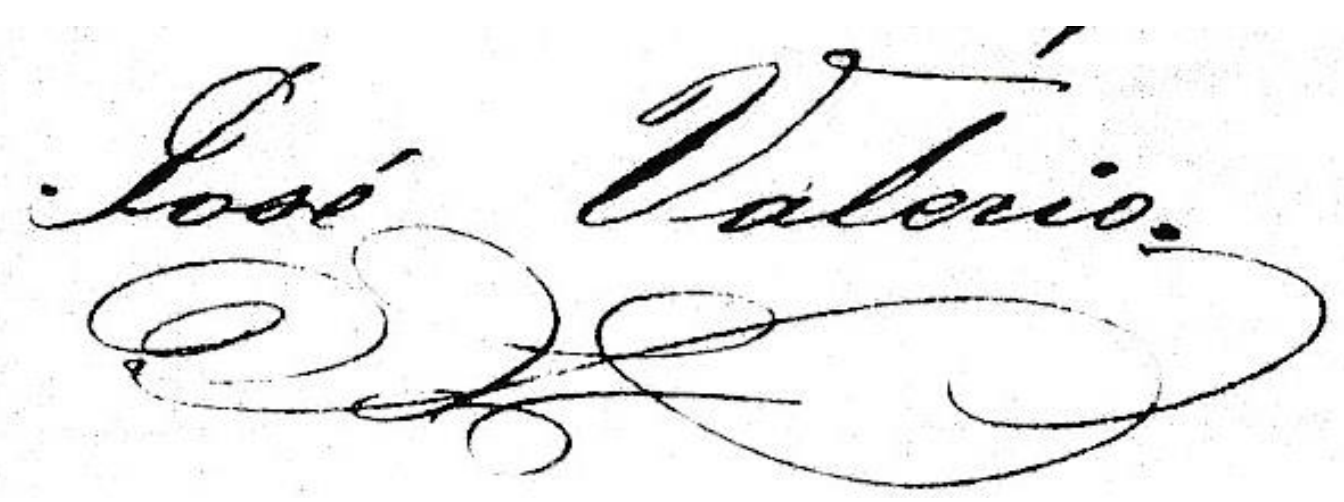

Fotografía: Miguel Bolaños Sequeira 
Revista Herencia, Vol. 35 (1), enero-junio, 2022.

\section{Apuntes sobre la vida de José Valerio Argüello}

El reconocimiento de José Valerio Argüello como un importante y fino escultor de imaginería religiosa, se hace desde la referencia puntual a su nombre en distintos libros de historia del arte en Costa Rica (Zeledón, 1993; Méndez, 1997; Ferrero, 2004; González, 2018). No obstante, solamente su hijo Rómulo Valerio-Rodríguez (1985), la periodista Norma Loaiza (1978 y 1982) y el historiador Leoncio Jiménez (2012), publicaron breves referencias biográficas de este imaginero.

José Valerio Argüello nació el 17 de diciembre de 1862 en Santo Domingo de Heredia, en el hogar formado por Rosario Valerio Ramírez y Francisca Gerónima Argüello González, quienes se casaron el 14 de julio 1847 en la Parroquia de la Inmaculada Concepción de María en Heredia. Fue bautizado en Santo Domingo de Heredia en el año 1862.

El matrimonio de Rosario y Francisca Gerónima fijó su residencia en Santo Domingo, en donde nacieron ocho hijos: Toribio, Juana Balvanera, Francisco, María Estéfana, María de Jesús, María Rafaela, José y Petra Rafaela.

El 21 de febrero de 1887 José contrajo matrimonio en la iglesia parroquial de Santo Domingo con Emilia Rodríguez Elizondo, de 20 años de edad, ambos vecinos de Santo Domingo. De esta unión nacieron diez hijos: Raquel, Otilia, Clementina, Rafael Ángel, Lucila, Alcides, Juvenal, Alicia, Rómulo y Remo.

La sensibilidad de artista de José le permitió reconocer cómo la sociedad costarricense de finales del siglo XIX e inicios del siglo XX estaba cambiando, y cómo la educación sería el eje principal de ese cambio, por lo que siempre inculcó en sus hijos el estudio y la superación, independientemente fueran hombres o mujeres. Es así como los hermanos y hermanas Valerio Rodríguez, en su gran mayoría fueron profesionales y docentes destacados. 
Revista Herencia, Vol. 35 (1), enero-junio, 2022.

Figura 5. Aparecen en la fotografía de izquierda a derecha, José Valerio Argüello y su yerno Albino Bolaños Vargas. Abajo su hija Raquel Valerio Rodríguez y su esposa Emilia Rodríguez Elizondo. Alrededor de 1910.

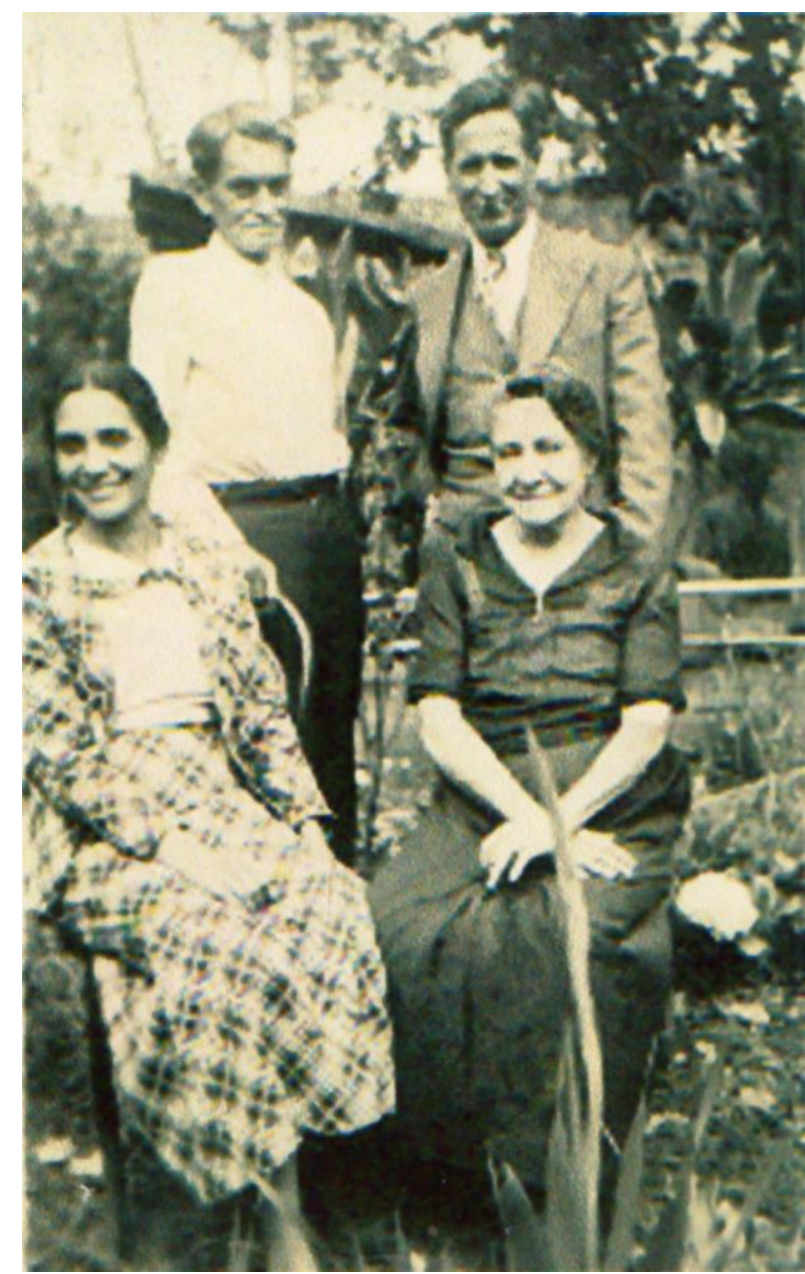

Fotografía: Archivo familia Bolaños Valerio.

La vida de José Valerio transcurrió predominantemente en su ciudad natal. En el campo de la política formó parte del Partido Constitucional, que proclamó la candidatura de Julio Acosta García para la Presidencia de Costa Rica en el período de 1920 a 1924. Fue nombrado, junto con otros distinguidos ciudadanos de Santo Domingo, como Presidente Honorario del Comité Electoral, además ocupó la Presidencia de la Junta de Educación en dicha ciudad. 
Revista Herencia, Vol. 35 (1), enero-junio, 2022.

Inició su quehacer artístico en 1879, a la edad de 17 años, con sus primeras esculturas, una de ellas con el tema de san Joaquín. El escultor Ólger Villegas, con motivo de la exposición sobre la obra del escultor, realizada en la Sala Julián Marchena del Museo de Arte Costarricense, antes mencionada, describió a José de la siguiente manera:

Apasionado y consumado conocedor de todos los secretos de su oficio, hace manifestación de ello en el hermoso acabado de sus obras en las que destacan la expresividad de sus rostros, delicados ademanes y actitudes, un magnífico pulimento y una viva policromía. El trato tan personal que logra en la ejecución de los pliegues de los ropajes, identifica y constituye, en gran medida, el estilo propio de este creador. Muy novedoso en la producción de José Valerio es que, estando en boga en su época los cánones y soluciones plásticas de los estilos castellano, precolombino y tirolés, se desentiende de ellos para buscar y aplicar a sus formas sus propias soluciones.

El destacado poeta Isaac Felipe Azofeifa, en una de las estrofas del Poema Cementerio, expresó lo siguiente:

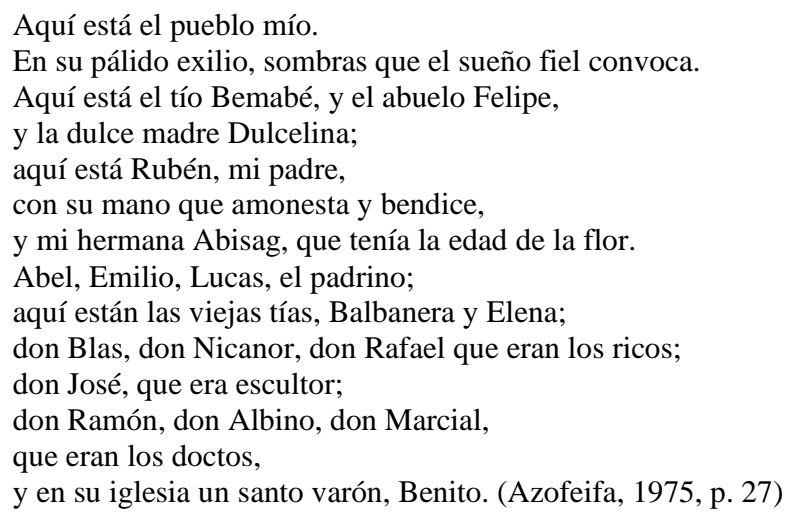

Resulta muy difícil realizar una semblanza sobre quién era José Valerio en su vida cotidiana, fuera de su trabajo artístico, esto debido a que quedan muy pocas personas vivas que lo hayan conocido. Una de las fuentes escritas más importantes es el libro "Prosa Vieja" escrito por su hijo Rómulo Valerio-Rodríguez. En lo escrito por su hijo se puede sostener lo que se describe en los siguientes párrafos.

Rómulo describe a su padre diciendo "... muy delgado, cuerpo recto y andar pausado, como si estos detalles fueran un reflejo de su carácter y de su vida" (Valerio-Rodríguez, 1985, p. 55). La casa de habitación de la familia Valerio Rodríguez era una construcción de paredes de adobe y cubierta de teja, ubicada dentro del cuadrante de la ciudad de Santo Domingo de Heredia, la puerta principal quedaba mirando hacia el norte. En el frente a la acera tenía dos salas, una hacia el este 
y la otra hacia el oeste, siendo esta última donde tenía su taller, contaba con un ventanal que le propiciaba la claridad suficiente. Comentaba el poeta Isaac Felipe Azofeifa, quien acostumbraba asomarse por dicha ventana para ver al escultor realizando su labor (Valerio-Rodríguez, 1985, p.76).

Figura 6. Vistas laterales y frontal de la imagen de santa Rosa de Lima, iglesia de Paracito de Santo Domingo de Heredia. (Obra no conserva la policromía original).
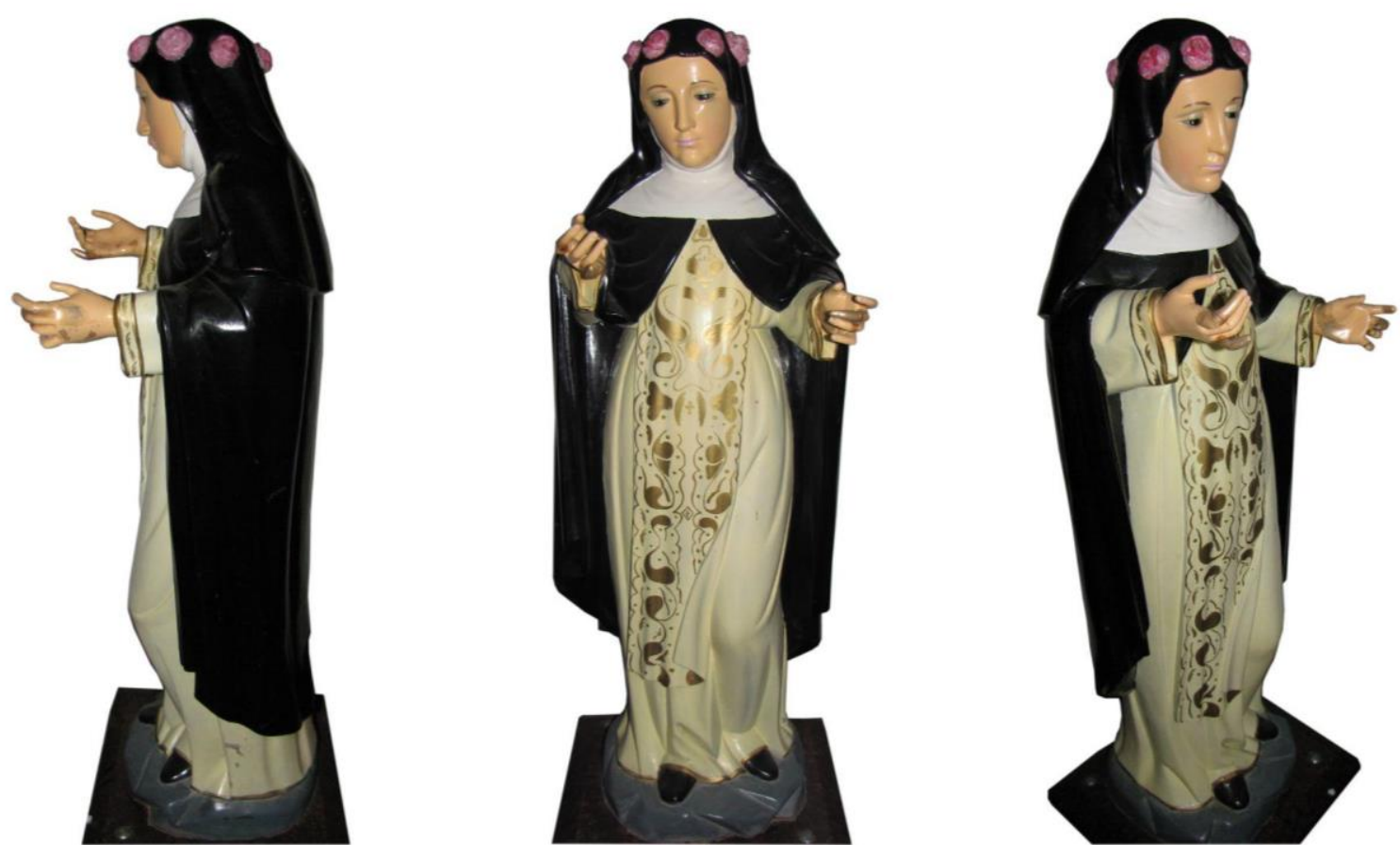

Fotografías: Luis Carlos Bonilla Soto

La vida en comunidad en el Santo Domingo de esa época era muy importante y se narra que José era un hombre generoso, pues constantemente dejaba su trabajo para construir puertas talladas, ventanas de madera, que eran requeridos por familiares y amigos. 
Revista Herencia, Vol. 35 (1), enero-junio, 2022.

Figura 7. San Antonio de Padua de la colección del Museo Nacional de Costa Rica (no conserva la policromía original).

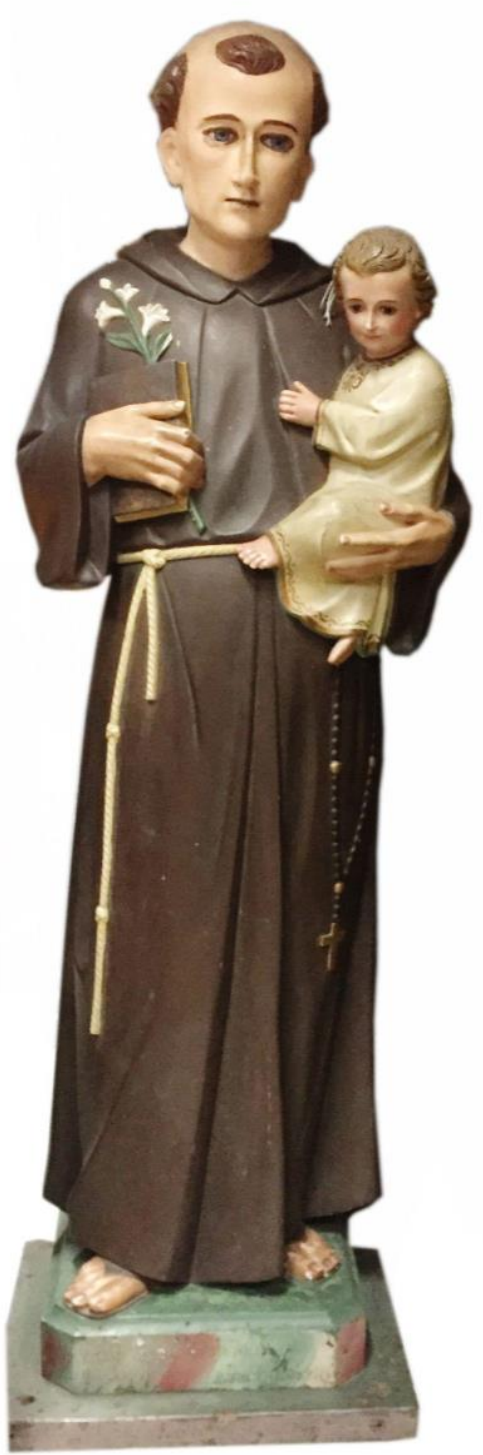

Fotografia: Departamento de Protección del Patrimonio Cultural - MNCR

En la casa de José y Emilia se vivía un ambiente artístico propiciado por ellos. Se tenía un piano y un violín que eran ejecutados por dos de sus hijos, era común realizar veladas de canto con vecinos que aportaban otros instrumentos. El taller era para José como un templo en donde no permitía que nadie entrara; todo tenía un orden estricto y una limpieza impecable. Cuando el artista 
Revista Herencia, Vol. 35 (1), enero-junio, 2022.

estaba en el proceso de colocar las láminas de oro en sus imágenes, nadie podía abrir la puerta del taller, no importaba el tiempo en dicha labor.

En una ocasión tuvo un contrato con la Iglesia de Moravia y, por el tamaño de las obras encargadas, no se podían realizar en su taller, por lo que todos los días le llevaban el almuerzo desde Santo Domingo hasta Moravia, ya que él salía de su casa de madrugada y regresaba de noche.

Existen recuerdos familiares de las esculturas de la Virgen Dolorosa y la del Nazareno que se encuentran en la Iglesia de San Joaquín de Flores y que se afirma fueron realizadas por Valerio Argüello (Guardia, 1992). En el libro de Valerio-Rodríguez (1985), se encuentra una anécdota que muestra lo difícil que era para los imagineros de esa época el que su trabajo fuera valorado adecuadamente:

\begin{abstract}
El tío Francisco Valerio encontró una botija trabajando en los terrenos de un cafetalero adinerado, se calculó en ese momento el valor en 200000 pesos. Al tío Francisco le dieron la suma de 100 pesos y al cura del pueblo el dinero para importar de España una imagen de la Virgen Milagrosa, para sustituir la hecha por el escultor local José Valerio (Valerio-Rodríguez, 1985).
\end{abstract}

En las reseñas y semblanzas de este imaginero, José siempre se refiere a sí mismo como artista, separándose en forma constante del término artesano. Al respecto Magda Barrantes en una conversación sostenida en 1976, con Raquel Valerio Rodríguez, su hija, pudo recopilar las palabras de su hija mayor, donde se pone de manifiesto el sentimiento que José tenía sobre su trabajo:

Cuando era una niña, llegó el momento de asistir a la escuela, en ese tiempo era algo muy especial, no era mal visto que las mujeres permanecieran en la casa y que no aprendieran a leer, escribir, sumar, en fin, todas esas cosas. Nuestra familia no era adinerada por lo que recibir esa educación era muy especial y representaba un sacrificio, se me insistía e indicaba con mucha claridad que debía aprovechar al máximo la oportunidad y aprender todo lo que me enseñaran.

Ese día significó en mi vida una ocasión muy especial y mi padre me acompañó hasta la Escuela.

Una vez en el salón de clase, la maestra fue llamando a cada niña y le fue preguntando su nombre, él de sus padres y la ocupación de cada uno. Anotaba cuidadosamente en una libreta la información que recibía de cada alumna.

Cuando llegó mi turno, le dije que no sabía cuál era el oficio de mi padre.

- Ella preguntó:

- ¿Qué hace tu padre en el día?

- Yo le indiqué que mi padre hacia "pasitos", e imágenes de santos.

- A lo que me respondió:

- Artesano

Cuando regresé a la casa me esperaban con gran emoción para que les contara con detalles lo que me había sucedido y así, "con aires de gran importancia”, les fui contando con mucho detalle todo lo vivido. Cuando llegué al momento en que la maestra me había indicado que el oficio de mi padre era "artesano", mi Papá se levantó de la mesa con el ceño muy fruncido y me dijo, mañana de nuevo te llevo a la escuela, y se retiró al taller.

Al día siguiente de nuevo muy temprano caminé acompañada de mi padre a la escuela, sentía mi pequeña mano en la suya que era fuerte y delicada. La Escuela quedaba cerca de la casa por lo que el trayecto era corto, la alegría y el aire fresco de la mañana lo hacían muy placentero, pero sobre todo era muy importante para mí que papá me 
Revista Herencia, Vol. 35 (1), enero-junio, 2022.

acompañara, ya que él siempre se levantaba muy temprano y se quedaba en el taller, incluso algunas veces mamá le llevaba el almuerzo cuando tenía muchos compromisos. Los niños teníamos terminantemente prohibido entrar ahí.

Cuando llegamos a la escuela le indique cual era el salón de clase, ya la maestra se encontraba presente, aún de su mano, llegamos hasta donde ella y después de las presentaciones correspondientes, le dijo:

Ayer usted le indicó a mi hija que mi oficio era "artesano", con una mirada y una entonación que no dejaba espacio a ninguna interpretación le proclamó:

- Yo estoy aquí para que usted corrija el error en su libreta y quiero verlo.

¡Yo soy un artista!

Su vida estuvo dedicada al arte, fue un apasionado de su trabajo. No se tiene conocimiento de cómo aprendió su oficio, pero se sabe que siempre estaba estudiando aspectos relacionados con el tema. Hasta en los últimos años de vida se mantuvo activo profesionalmente, aunque por temporadas cortas, residió en Tilarán, Cañas, Alajuela y Heredia. Después de tan amplia y profusa actividad artística, murió en julio de 1946, a los 84 años de edad.

Figura 8. Detalle de manos de ángel de Moravia durante decape y resultado final del proceso de restauración
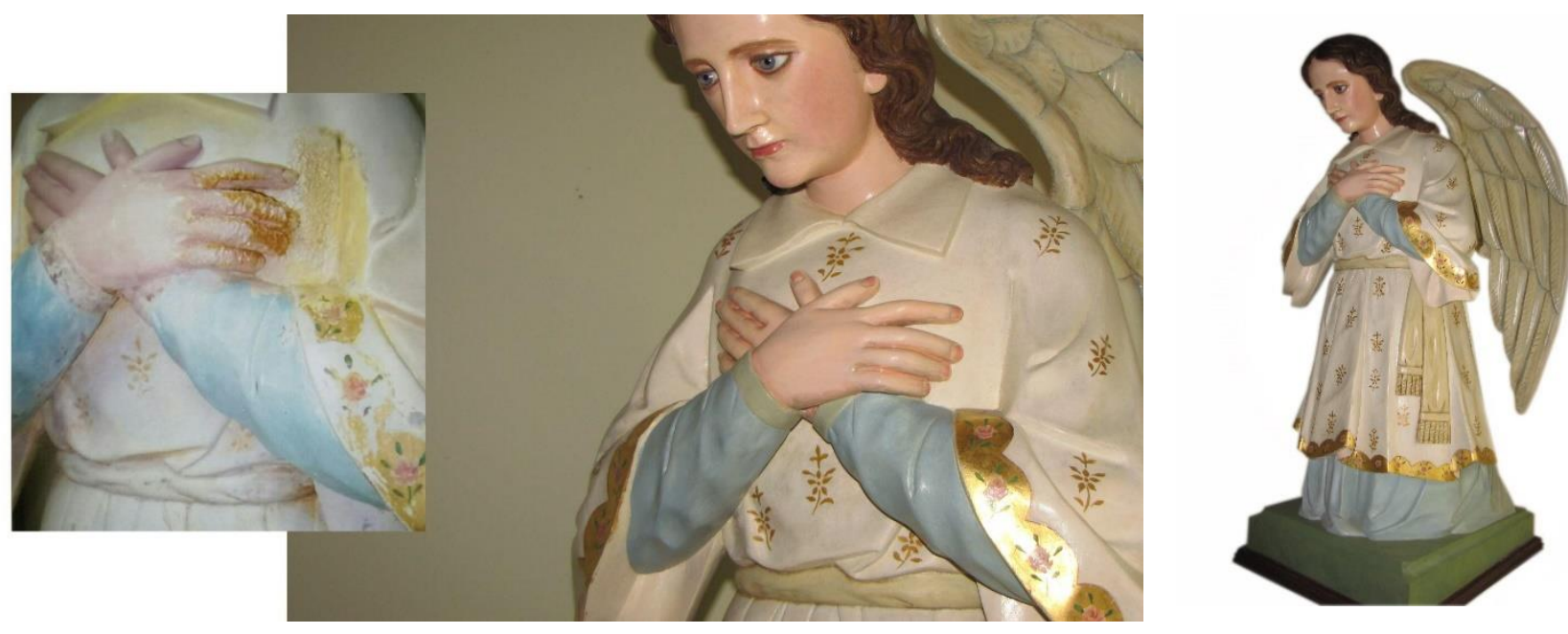

Fotografías: Mercedes Fontana y Luis Carlos Bonilla Soto 
Revista Herencia, Vol. 35 (1), enero-junio, 2022.

Figura 9. Pasito entregado por el artista a su hija Raquel Valerio Rodríguez en ocasión de su matrimonio con Albino Bolaños Vargas el 5 de diciembre de 1910.

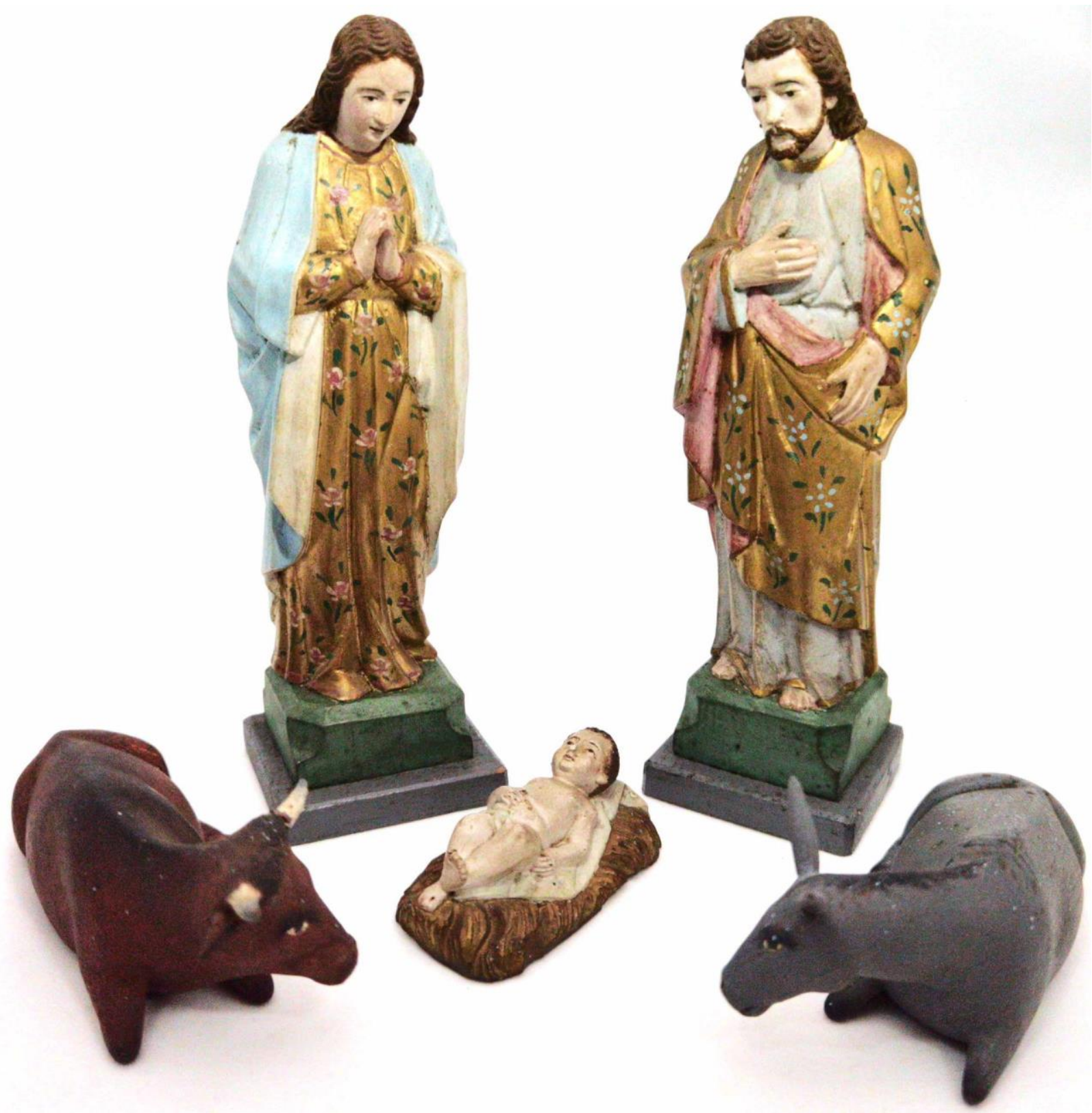

Fotografía: Luis Carlos Bonilla Soto 
Revista Herencia, Vol. 35 (1), enero-junio, 2022.

\section{La imaginería de Valerio Argüello}

Valerio Argüello trabajó una amplia diversidad de temas del santoral, en los cuales el artista atendió al canon eclesiástico que dictaba los atributos y las disposiciones de las personas representadas. En el catálogo de la exposición sobre la obra de José Valerio, realizada del 7 de diciembre de 1978 al 7 de enero de 1979 en la sala Julián Marchena del Museo de Arte Costarricense en la Sabana, se detectan veintidós temas distintos entre las cuarenta obras exhibidas en ese momento, las cuales fueron elaboradas entre 1879 y 1944 . A saber:

1. Dulce Nombre

2. Cristo agonizante / crucifijo

3. Corazón de Jesús

4. Jesús (no especifican advocación)

5. Niño Jesús

6. Nazareno

7. "Paso" (conjunto del nacimiento)

8. Inmaculada Concepción

9. Virgen Dolorosa

10. Virgen del Socorro

11. Virgen del Carmen

12. San José

13. Santa María Magdalena

14. San Joaquín

15. Santa Ana

16. Santa Cecilia

17. San Blas

18. San Cayetano

19. Santa Teresita

20. Santa Marta

21. San Antonio

22. San Rafael Arcángel (con y sin Tobías) 
Revista Herencia, Vol. 35 (1), enero-junio, 2022.

Figura 10. Santa Marta entregada por el artista a su nieta Marta Bolaños Valerio en ocasión de su matrimonio con Claudio Murillo Alfaro en 1936. (Conserva la policromía original)

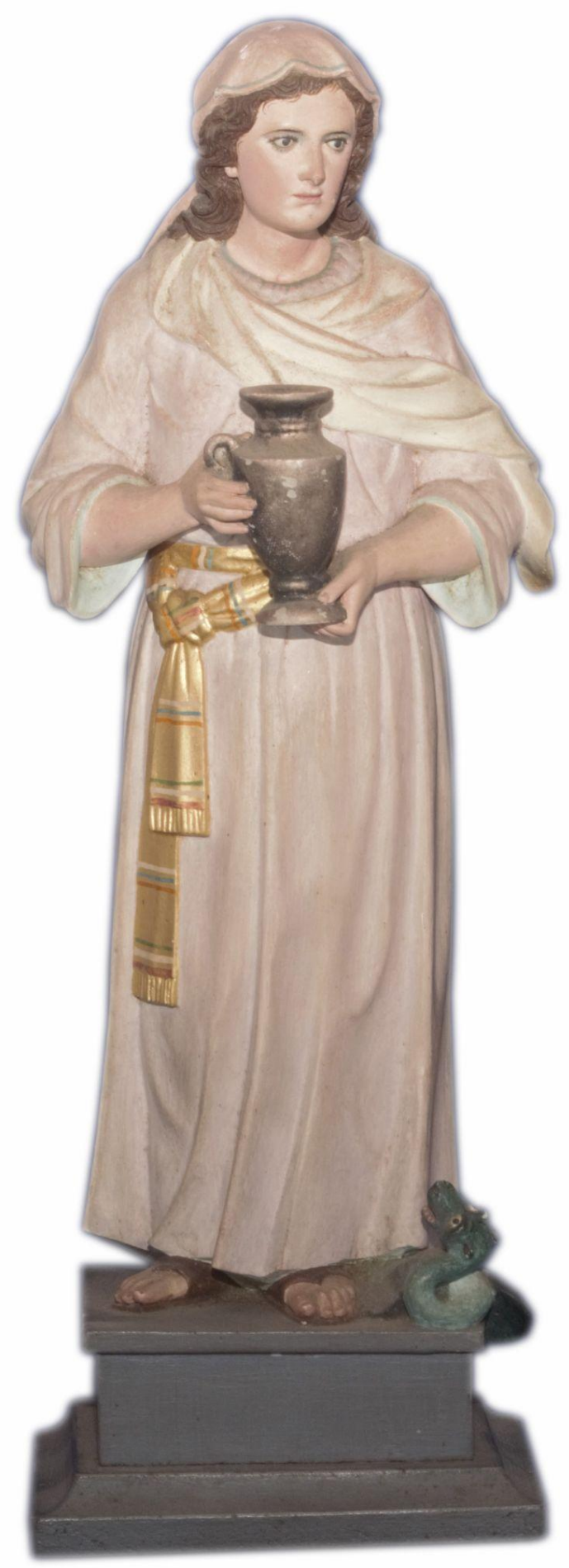

Fotografía: Miguel Bolaños Sequeira 
Revista Herencia, Vol. 35 (1), enero-junio, 2022.

Rómulo Valerio-Rodríguez (1985), señalaba que el pesebre de la casa de su padre "tenía la mula gris y el buey josco" (p.11), y que esta es una característica que mantuvo en todos los "pasos" que realizó y que se ha corroborado en los pasitos analizados en esta investigación, por lo que esto se puede convertir en un rasgo identificador de su autoría. La madera que utilizó preferentemente en sus trabajos fue el cedro. El artista sentía predilección por el cedro del Pacífico seco y con frecuencia él mismo iba a recogerlo a Balsa o Jesús María, en los cantones alajuelenses de Atenas y San Mateo, respectivamente.

Leoncio Jiménez (2012) indica que la imaginería de Valerio se halla concentrada probablemente en la comunidad de Santo Domingo de Heredia y sus alrededores, y que su obra comprende principalmente obra en pequeño formato. No obstante, a partir de lo recogido de la tradición familiar y lo apuntado por Guardia (1992), José Valerio esculpió obras de imaginería para el culto público en distintas iglesias costarricenses, tales como el Nazareno y la Dolorosa de San Joaquín de Flores antes mencionadas, el Cristo yacente que elaboró junto con un santo sepulcro para la iglesia La Dolorosa en San José (sin localizar), los ángeles de adoración de la iglesia de San Vicente de Moravia (ver figura 8) y la imagen de la Inmaculada Concepción que fue regalada a la iglesia de San Pedro de Turrubares. Estas obras permiten constatar que el fino trabajo observado en las imágenes domésticas de pequeño formato, también fue plasmado en otras de mayor tamaño destinadas al culto público realizado en iglesias de Costa Rica.

A partir de las veintiocho imágenes analizadas para la identificación de obras atribuibles (ver cuadro 1), se observaron rasgos constantes en lo que se refiere a la forma de tallar la madera, el diseño de los elementos policromados, así como la composición de la gestualidad y los atributos de los distintos personajes. En lo que se refiere a la técnica de tallado, Valerio Argüello trabajó las cabelleras largas y las barbas de los personajes con trazos profundos y con líneas bien definidas en su recorrido y caída. Otra constante es la elaboración de bocas pequeñas con los labios contraídos.

En las extremidades se observan las manos con los dedos alargados y en los pies de los personajes adultos el segundo dedo es más largo (este rasgo es común en algunas obras llegadas a Costa Rica desde las escuelas de imaginería escultórica guatemalteca). En general los personajes esculpidos 
Revista Herencia, Vol. 35 (1), enero-junio, 2022.

evocan movimientos suaves, sin dramatismos en las posturas y los gestos. Norma Loaiza (1978; 1982), dice que no hay estatismo en las creaciones del autor, pero esto no significa que existan despliegues abruptos de movimientos, pues lo que prima son expresiones que evocan calma.

Figura 11. Santa Cecilia de la parroquia de San Pedro de Poás, Alajuela

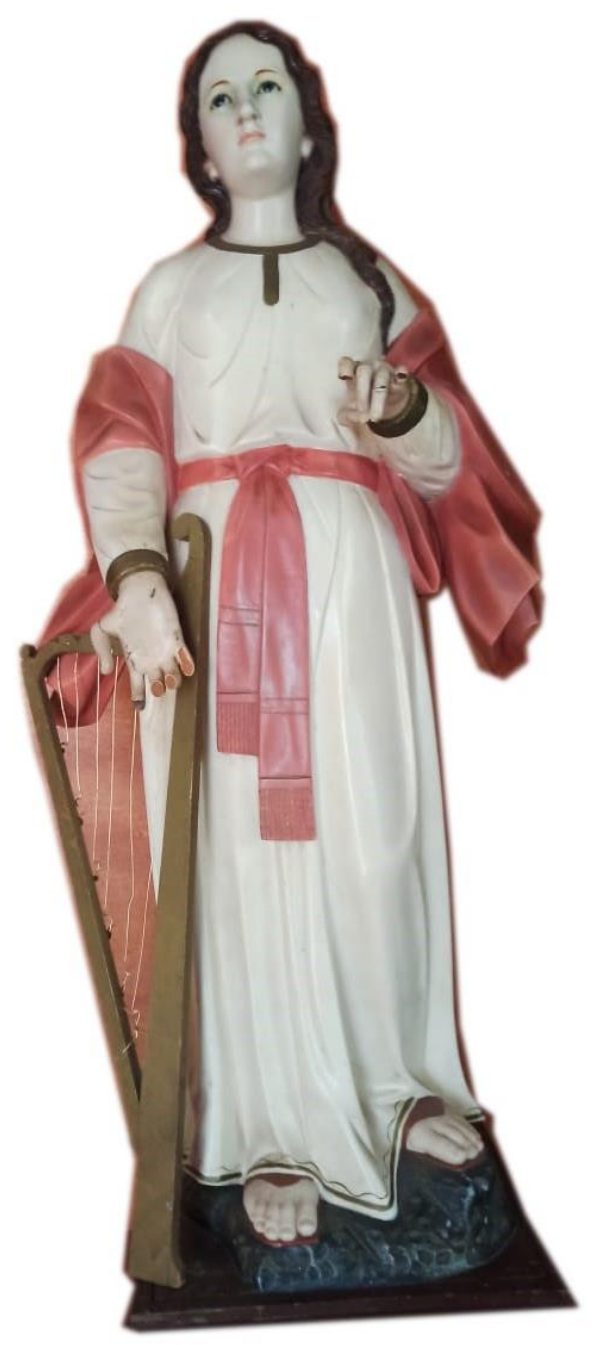

Fotografía: Parroquia san Pedro de Poás

Existe, asimismo, una ejecución personalizada en lo referente a los pliegues de los ropajes y a la forma en que el escultor ciñe la cintura de los personajes, la cual consiste, en muchos casos, en una banda que cae al lado o al centro a partir de un nudo (ver figuras 8, 10 y 11), la misma es la que define la forma en que se curvan los pliegues de manera marcada hacia abajo en la vestimenta. 
Revista Herencia, Vol. 35 (1), enero-junio, 2022.

Esto lo emplea principalmente en las figuras de santas y de los ángeles, no así en las figuras del pasito o Belén.

En el caso de la policromía, solamente se valoraron las obras que conservan los rasgos originales o en las que se observaron algunos rastros de originalidad. En ellas se destaca el modo cómo el artista pintaba sobre los dorados las decoraciones de pequeñas flores, las cuales le dan un estilo particular de estampados a la vestimenta que realiza a los personajes en las orlas y partes más extensas de la ropa (ver figuras 8 y 9). Al respecto, Ólger Villegas Cruz (1978), en el catálogo de la exhibición en el Museo de Arte Costarricense 1978-79, afirmaba "un magnífico pulimento y una viva policromía”.

Cuadro 1. Obras confirmadas y atribuibles a José Valerio según ubicación, Arquidiócesis de San José.

\begin{tabular}{|l|l|}
\hline Obra confirmada & \multicolumn{1}{|c|}{ Ubicación } \\
\hline Crucifijo & Colección familiar \\
\hline Corazón de Jesús & Colección familiar \\
\hline Niño del pasito & Colección familiar \\
\hline Niño del pasito & Colección familiar \\
\hline Niño del pasito & Colección particular \\
\hline Niño del pasito & Colección particular \\
\hline $\begin{array}{l}\text { Inmaculada } \\
\text { concepción }\end{array}$ & Parroquia de Turrubares \\
\hline $\begin{array}{l}\text { Inmaculada } \\
\text { Concepción }\end{array}$ & Colección familiar \\
\hline Virgen del pasito & Colección familiar \\
\hline Virgen del pasito & Colección familiar \\
\hline Virgen del pasito & Colección particular \\
\hline Virgen del pasito & Colección particular \\
\hline San José del pasito & Colección familiar \\
\hline
\end{tabular}

\begin{tabular}{|l|l|}
\hline \multicolumn{1}{|c|}{ Obra atribuible } & \multicolumn{1}{c|}{ Ubicación } \\
\hline Crucifijo & Iglesia Santa Rosa \\
\hline Crucifijo & Iglesia San Luis \\
\hline Nazareno & Iglesia San Joaquín \\
\hline Dolorosa & Iglesia San Joaquín \\
\hline Virgen del socorro & Iglesia San Vicente \\
\hline Ángel adorador & Iglesia San Vicente \\
\hline Ángel adorador & Iglesia San Vicente \\
\hline San Luis Gonzaga & Iglesia San Luis \\
\hline San Rafael & Iglesia San Rafael \\
\hline San Rafael & Iglesia San Rafael \\
\hline San Rafael & Iglesia San José \\
\hline Santa Cecilia & Iglesia San Pedro \\
\hline Santa Rosa & Iglesia de Paracito \\
\hline
\end{tabular}


Revista Herencia, Vol. 35 (1), enero-junio, 2022.

\begin{tabular}{|c|c|}
\hline San José del pasito & Colección familiar \\
\hline San José del pasito & Colección particular \\
\hline San José del pasito & Colección particular \\
\hline Buey del pasito & Colección familiar \\
\hline Buey del pasito & Colección familiar \\
\hline Buey del pasito & Colección particular \\
\hline Mula del pasito & Colección familiar \\
\hline Mula del pasito & Colección familiar \\
\hline Mula del pasito & Colección particular \\
\hline Rafael y Tobías & Colección familiar \\
\hline Rafael arcángel & Colección particular \\
\hline Santa Marta & Colección familiar \\
\hline San Cayetano & Colección familiar \\
\hline $\begin{array}{l}\text { San Antonio de } \\
\text { Padua }\end{array}$ & Museo Nacional de CR \\
\hline Santa Teresita & Colección familiar \\
\hline
\end{tabular}

\begin{tabular}{|l|l|}
\hline San José & Iglesia de Fraijanes \\
\hline
\end{tabular}

Fuente: Elaboración propia

Figura 12. Imagen de María Auxiliadora para la iglesia de San Juan de Tibás (Se desconoce su paradero) 
Revista Herencia, Vol. 35 (1), enero-junio, 2022.

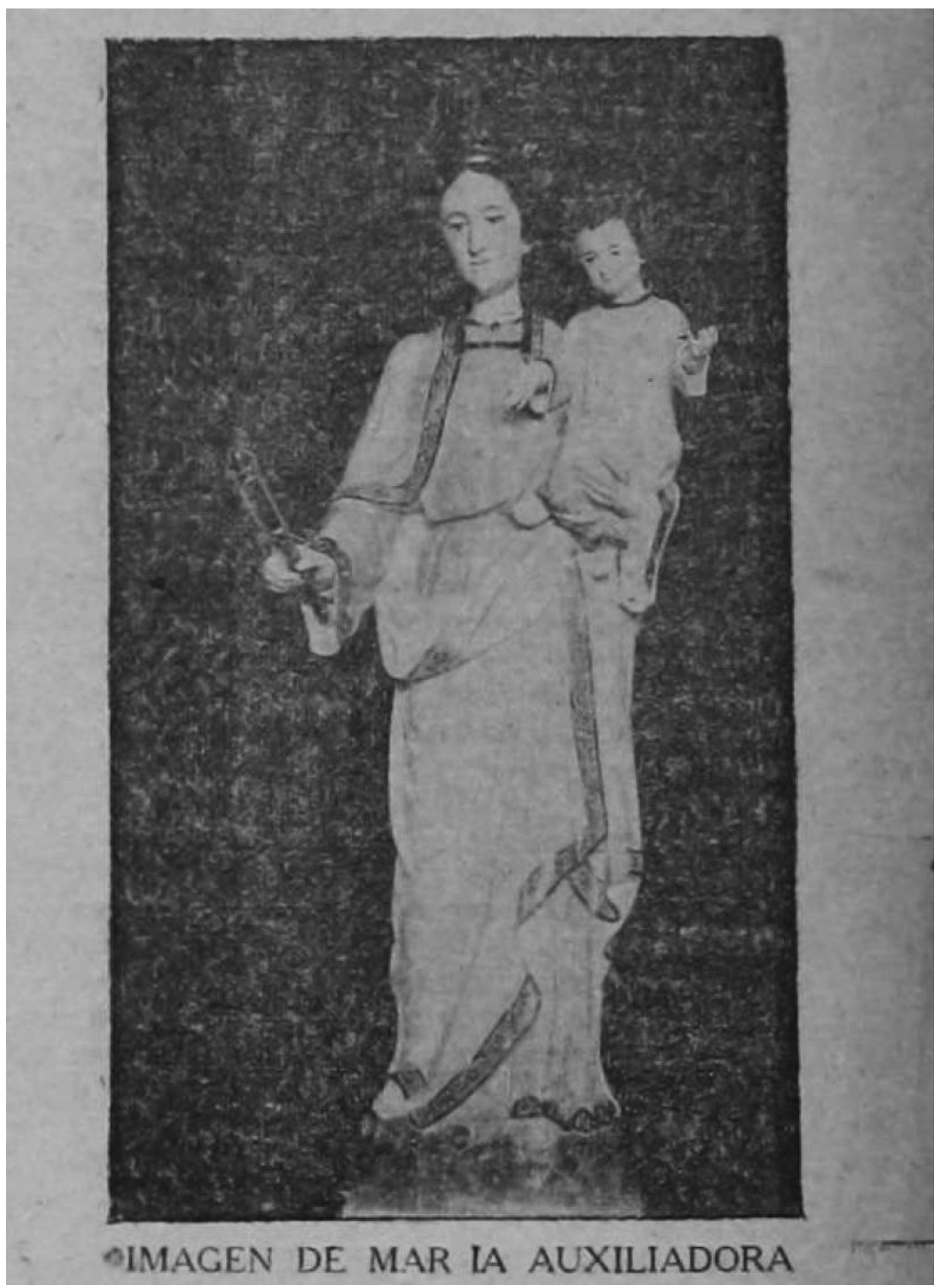

Fuente: Periódico La Información, 2 de Julio de 1916, página 5 
Revista Herencia, Vol. 35 (1), enero-junio, 2022.

\section{Conclusiones}

El estudio de obras de imaginería para definir atribuciones de autoría en Costa Rica requiere investigaciones rigurosas y exhaustivas de fuentes documentales, principalmente archivos familiares y notas de prensa de época. En el caso del escultor José Valerio Argüello, las fuentes documentales han sido de difícil consecución y las fuentes orales son muy limitadas. No se encontró en manos de descendientes archivos personales del artista, tampoco se hallaron bocetos ni pinturas de su autoría; esto pese a que se afirma que él también elaboró obra pictórica y dibujos.

Entre los rasgos distintivos de la obra escultórica de Valerio Argüello se encuentran su trabajo fino y muy marcado en cabelleras, barbas y pliegues de las vestimentas, así como el diseño de las flores sobre los dorados en la policromía. Estas características pueden facilitar futuras comparaciones y establecer rutas de identificación de otras obras de imaginería de su autoría, para lo cual es necesario una triangulación con otros tipos de información histórica (documental y oral), que permitan establecer conexiones entre las obras y los contextos en los que se hallan o se han encontrado.

Por otra parte, los resultados de investigación acá presentados, además de permitir el avance en la identificación de obras de este artista en particular, pueden ayudar en la comprensión de la vida y dinámicas del oficio de los imagineros, sus talleres y las relaciones que estos establecían con sus familiares, otros miembros del gremio y con compradores de obras religiosas para uso doméstico y para veneración en las iglesias de los pueblos.

Pese a las limitantes presentes en la búsqueda de información, se pudo corroborar que José Valerio se autodenominó como un artista, fue celoso y riguroso de su oficio, creó obras de fina talla y sobria policromía, resolvió un abanico amplio de representaciones de nacimiento o Belén y del santoral católico, elaboró imágenes para las iglesias josefinas, heredianas y alajuelenses, tuvo relación con artistas e intelectuales de su época y se involucró en distintas actividades comunales de Santo Domingo de Heredia, que le valen un nombre importante en las artes costarricenses.

\section{BIBLIOGRAFIA}


Revista Herencia, Vol. 35 (1), enero-junio, 2022.

Azofeifa, I. F. (1975). Mundo, vida y poesía o autolectura para explicarme. Revista de Filología y Lingüística de la Universidad de Costa Rica, 1(2), 3-28. doi: 10.15517/rfl. v1i2.15029.

Bolaños-Villalobos, R. (1999). Al Occidente del Abra. Historia monográfica de Santo Domingo de Heredia. Editorial Centro de Estudios e Investigaciones Sociales.

Bonilla-Soto, L. C. (2018). El legado imaginero de Manuel María Zúñiga Rodríguez». Revista Herencia, 31(1), 57-78. doi: 10.15517/h. v31i1.34059.

Bonilla-Soto, L. C. (2019). Herencia en metal: Registro de las obras de arte sacro de los $\begin{array}{lllll}\text { orfebres del } \quad \text { Valle. } & \text { Revista }\end{array}$ https://www.revistas.ucr.ac.cr/index.php/herencia/article/view/40258

Carrera-Umaña, R. (2020). Teología y filosofía de la imagen en Juan Damasceno. InterSedes, 21(44), 118-130. doi:10.15517/isucr.v21i44.43939

Diéguez-Melo, M. (2016). Fundamentos Teóricos Del Arte Sacro Contemporáneo (II): El arte en el magisterio de la Iglesia (1962-2015). Revista Brasiliensis, 5(9), 155-216. https://www.academia.edu/40306383/Fundamentos_te\%C3\%B3ricos_del_arte_sacro _contempor\%C3\%A1neo_I_El_arte_en_el_magisterio_de_la_Iglesia_1962_2015_

Ferrero, L. (2004). Sociedad y arte en la Costa Rica del siglo XIX. Editorial Universidad Estatal a Distancia.

González, A. (2018). De Santos e Imagineros. Los orígenes de la escultura en Costa Rica. Editorial Universidad Estatal a Distancia.

Guardia, E. (1992). Vandalismo artístico. En Arte y Literatura. pp. 161-163. 
Revista Herencia, Vol. 35 (1), enero-junio, 2022.

Jiménez, L. (2012). “Escultores costarricenses entre 1821 y 1950”. En: Boletín AFECHC. $\mathrm{N}^{\mathrm{o}} 52$.

Loaiza, N. (8 de octubre de 1978). José Valerio. Conocedor de todos los secretos de su oficio. En: La Nación. San José, CR. pp. 7-8.

Loaiza, N. (1982). La abundancia y el tiempo. Editorial Universidad Estatal a Distancia.

Lorite-Cruz, P. (2010). La línea que separa el Arte del no Arte en la imaginería religiosa. Algunos ejemplos de la ciudad de Úbeda. Trastámara. No 5, 25-41. https://dialnet.unirioja.es/servlet/articulo?codigo=3734325

Méndez, R. (1997). Lico Rodríguez. Escultor de imaginería religiosa. San José: EUNED. Museo de Arte Costarricense (1978). Catálogo de exhibición “José Valerio”. Sala Julián Marchena. Ministerio de Cultura.

Parroquia Santo Domingo de Heredia. (1853-1871). Asiento 576. Libro 1 de Bautizos. https://www.familysearch.org/ark:/61903/3:1:S3HY-DC13-

8FL $? \mathrm{i}=328 \& \mathrm{cc}=1460016 \&$ personaUrl=\%2Fark\%3A\%2F61903\%2F1\%3A1\%3ANQ G4-R8T

Parroquia Santo Domingo de Heredia. (1886-1892). Asiento 9. Libro 3 de Matrimonios. https://www.familysearch.org/ark:/61903/3:1:S3HT-6S3Q9J2?i=12\&cc=1460016\&personaUrl=\%2Fark\%3A\%2F61903\%2F1\%3A1\%3ANQG Z-YZ3

Rojas, J. N. (2008). No se extrañe si lo asustan... un repaso a las motivaciones presentes en la creación de la escultórica religiosa y su impacto en la imaginería costarricense. $\begin{array}{lll}\text { Revista Herencia, } & \text { 57-77. }\end{array}$ https://revistas.ucr.ac.cr/index.php/herencia/article/view/10061 
Revista Herencia, Vol. 35 (1), enero-junio, 2022.

Vargas-Benavides, H. (2018). Paisaje y diseño en torno a la construcción del templo de San Miguel Arcángel, Santo Domingo de Heredia, Costa Rica, 1879. Cuadernos Inter.c.a.mbio sobre Centroamérica y el Caribe, 15(2), 64-94. doi: 10.15517/c.a. v15i2.34641

Valerio-Rodríguez, R. (1985). Prosa vieja. EUNED.

Zeledón, E. (1993). La Navidad Costarricense. Editorial Universidad de Costa Rica. 
Revista Herencia, Vol. 35 (1), enero-junio, 2022. 